\title{
ZARYS PROBLEMATYKI ETYKI FINANSÓW
}

\begin{abstract}
Streszczenie: Konsekwencje kryzysów na rynkach finansowych $w$ postaci utraty zaufania przez klientów wobec systemu finansowego spowodowaty wzrost zainteresowania etyka biznesu a zwłaszcza etyka finansów. Etyka finansów stopniowo zyskuje coraz większe znaczenie w dyskursie naukowym. Celem niniejszego rozdziatu jest przedstawienie sensu pojęciowego i identyfikacja katalogu zagadnień zwiąanych z etyka $w$ finansach, stanowiacych obszar badawczy etyki finansów oraz próba oceny jej wielowymiarowości. Pojawia się w tym przypadku pytanie badawcze, czy wystęujące $w$ systemie finansowym potencjalne zagrożenia determinuja potrzebe etycznych dziatań. Metodę wykorzystywana do realizacji celu i poszukiwania odpowiedzi na pytanie stanowita krytyczna analiza krajowej $i$ zagranicznej literatury. W wyniku przeprowadzonych analiz zauwa$\dot{z}$ ono, że $w$ operacjach zwiazanych $z$ finansami występuja dylematy $i$ wyzwania etyczne oraz $\dot{z} e$ warto ksztaltować wzorce zachowań osobowych, a także standardy postępowania etycznego pracowników, menedżerów, instytucji oraz konsumentów.
\end{abstract}

Słowa kluczowe: system finansowy, sektor bankowy, etyka biznesu, etyka finansów.

Motto: (...) nie człowiek jest dla gospodarki, ale gospodarka jest dla człowieka. Człowiek nie może stać się ofiara systemu finansowego, ale system finansowy ma stużý czlowiekowi.

Nie człowiek jest dla finansów, lecz finanse sa dla człowieka. (O. Bazzichi, Etyka biznesu, „Społeczeństwo” 2004, rok XIV, nr 3).

\section{WSTĘP}

Konsekwencje kryzysów na rynkach finansowych w postaci utraty zaufania przez klientów wobec systemu finansowego spowodowały wzrost zainteresowania etyką biznesu, a zwłaszcza etyką finansów. $Z$ jednej strony etyka finansów stopniowo zyskuje coraz większe znaczenie w dyskursie naukowym i biznesowej praktyce, ale $\mathrm{z}$ drugiej strony występuje istotna luka w tej dziedzinie, warta zagospodarowania, co może stanowić impuls do powiększenia nielicznych badań i publikacji w tym zakresie. Trzeba przyznać, że w piśmiennictwie polskim dotychczasowa uwaga autorów skoncentrowana była raczej na etyce biznesu (m.in. opracowania takich uznanych autorów jak: W. Gasparski, A. Lewicka-Strzałecka, J. Klimek), a także na szczegółowych tematach związanych z etyką finansów, brakuje natomiast pozycji o charakterze uogólniającym ${ }^{1}$, stąd wybór

\footnotetext{
* Prof. UŁ dr hab. Iwona Dorota Czechowska, Wydział Ekonomiczno-Socjologiczny, Uniwersytet Łódzki. biński.

${ }^{1}$ Niekwestionowanym liderem wśród autorów publikacji z etyki finansów jest P. H. Dem-
} 
tematu, mającego walor społeczno-gospodarczy wydaje się być uzasadniony i użyteczny, a zarazem ciekawy teoretycznie. Celem niniejszego rozdziału jest przedstawienie sensu pojęciowego i identyfikacja katalogu zagadnień związanych $\mathrm{z}$ etyką $\mathrm{w}$ finansach, stanowiących obszar badawczy etyki finansów oraz próba oceny jej wielowymiarowości. Pojawia się w tym przypadku pytanie badawcze, czy występujące w systemie finansowym potencjalne zagrożenia determinują potrzebę etycznych działań. Metodę wykorzystywaną do realizacji celu i poszukiwania odpowiedzi na pytanie stanowiła krytyczna analiza krajowej i zagranicznej literatury. W pracy wykorzystano jako ilustracje statystyki NBP. Opracowanie podzielono na dwie zasadnicze części. Pierwsza $\mathrm{z}$ nich koncentruje się na kluczowych kwestiach związanych z przedstawieniem istoty systemu finansowego, a druga ukazuje wielowymiarowość etyki finansów - dziedziny naukowej, odnoszącej się do etyki w finansach, wstępującej w praktyce biznesowej.

\section{DEFINIOWANIE POJĘCIA SYSTEM I SEKTOR FINANSOWY, OKREŚLENIE ZNACZENIA SYSTEMU FINANSOWEGO I ROLI SEKTORA BANKOWEGO}

Zapowiedziane $\mathrm{w}$ tytule skoncentrowanie rozważań na sektorze finansowym wymaga doprecyzowania tego pojęcia oraz przedstawienia przeglądu podejść do analizy systemu finansowego. Dalszym krokiem będzie zwrócenie uwagi na jego powiązania $\mathrm{z}$ gospodarką i podkreślenie zasadniczej roli $\mathrm{w}$ tym systemie instytucji bankowych.

Finanse są zjawiskiem złożonym, często prezentowanym poprzez wskazanie ich funkcji takich jak: generowanie, alokację, wymianę, zarządzanie środkami pieniężnymi. Główne obszary finansów dotyczą finansów osobistych, obejmujących różne operacje klientów indywidualnych, począwszy od oszczędzania, inwestowania, a skończywszy na pożyczaniu środków pieniężnych. Kolejny obszar to finanse korporacyjne, w ramach których przedsiębiorstwa pozyskują kapitał poprzez emisję papierów wartościowych i wykorzystują go do najbardziej efektywnych przedsięwzięć. Ponadto istotną sferą finansów są finanse publiczne, dzięki którym rząd pozyskuje poprzez podatki i pożyczki dochody, które wykorzystuje świadcząc obywatelom usługi. Ten rodzaj aktywności jest oferowany na różnych rynkach i przez różne instytucje finansowe. Finanse stanowią także dyscyplinę akademicką ${ }^{2}$. W literaturze przedmiotu obszary aktywności instytucji finansowych są często ujmowane zgodnie z dwoma koncepcjami: szerszą i węższą ${ }^{3}$. Podejście szersze prezentuje system finansowy, definio-

${ }^{2}$ J. R. Boatright, Finance Ethics: Critical Issues in Theory and Practice, John Wiley \& Sons, New Jersey 2010, s. 3-4.

${ }^{3}$ R. H. Schmidt, M. Tyrell, What Constitutes a Financial System in General and the German Financial System in Particular, Johann Wolfgang Goethe - Universität Frankfurt am Main 
wany, jako powiązania między podażą i popytem, których celem jest dostarczanie kapitału i innych usług finansowych ${ }^{4}$. W tym ujęciu system finansowy stanowi element systemu ekonomicznego, będącego częścią systemu społecznego ${ }^{5}$. System finansowy wraz ze sferą realną tworzy gospodarkę. Pojęciem zbliżonym do systemu finansowego, chociaż o węższym zakresie jest sektor finansowy. Sektor finansowy to sektor gospodarki, który oferuje i dostarcza usługi finansowe innym sektorom. Ważny element systemu finansowego stanowi instytucja kredytowa.

Pojęcie instytucji kredytowej jest opisane w europejskim prawie bankowym, także w odpowiednich regulacjach w Polsce ${ }^{6}$. Można zauważyć w tym przypadku brak precyzji legislacyjnych a także występowanie niejasności pojęciowych. Jeden z problemów stanowi odróżnienie instytucji kredytowej od finansowej. Zgodnie $\mathrm{z}$ pierwszą dyrektywą bankową ${ }^{7}$ instytucja kredytowa to instytucja, której działalność polega na przyjmowaniu depozytów oraz innych funduszy pod tytułem zwrotnym oraz udzielanie kredytów na własny rachunek. W drugiej dyrektywie bankowej ${ }^{8}$ dodano do tej definicji zastrzeżenie, że tylko instytucje kredytowe mogą prowadzić wskazaną w tej dyrektywie działalność. W dyrektywie nr 2000/28 rozszerzono pojęcie instytucji kredytowej na instytucję pieniądza elektronicznego ${ }^{9}$.

Problem definicyjny polega na tym, że w literaturze ${ }^{10}$ oraz regulacjach prawnych $^{11}$ instytucja kredytowa jest szczególnym rodzajem szerszej kategorii,

Fachbereich Wirtschaftswissenschaften, Working Paper Series: Finance \& Accounting no. 111, 2003, s. 3, http://hdl.handle.net/10419/76926 [dostęp: 7.11.2015].

${ }^{4}$ Ibidem.

${ }^{5}$ B. Pietrzak, Z. Polański, B. Woźniak (red.), System finansowy w Polsce, Wydawnictwo Naukowe PWN, Warszawa 2008, s. 15-17.

${ }^{6} \mathrm{~W}$ opracowaniu tego fragmentu tekstu korzystano z I. D. Czechowska, Przeglad definicji banku stanowiacego aktywny kanat dystrybucji produktów ubezpieczeniowych, „Acta Universitatis Lodziensis. Folia Oeconomica" 2011, nr 259, s. 25-27.

${ }^{7}$ 77/780/EEC - First Council Directive of 12 December on the Coordination of the Laws, Regulations and Administrative Provisions Relating to the Taking up and Pursuit of the Business of Credit Institutions, O. J., nr L322, 17.12.1977.

${ }^{8}$ 89/299/EEC - Second Council Directive of 18 December 1989 on the Ccoordination of the Laws Regulations and Administrative Provisions Relating to the Taking up and Pursuit of the Business of Credit Institutions and Amending Directive, 77/780/EEC, O. J., nr L 386, 30.12.1989.

${ }^{9}$ Directive 2000/12/EC of the European Parliament and the Council of 20 March 2000 Relating to Taking up and Pursuit of the Business of Credit Institutions, O. J., nr L 126, 26.05.2000.

${ }^{10}$ Instytucje finansowe przyjmujące depozyty i tworzące pieniądz, do których należą przede wszystkim banki oraz pozostałe instytucje, rozdzielające jedynie uprzednio ulokowane oszczędności. L. Oręziak, Rynek finansowy Unii Europejskiej, Biblioteka Bankowca, Warszawa 1999, s. 15-16; zob. także: B. Pietrzak, Z. Polański (red.), System finansowy w Polsce, Lata dziewięćdziesiąte, Wydawnictwo Naukowe PWN, Warszawa 1997, s. 17-18; W. Dębski, Rynek finansowy i jego mechanizmy. Podstawy teorii i praktyki, Wydawnictwo Naukowe PWN, Warszawa 2002, s. 15.

${ }^{11} \mathrm{~W}$ artykule 12 ustawy o działach administracji rządowej w dziale „instytucje finansowe” są wymienione sprawy banków, zakładów ubezpieczeń, funduszy powierniczych i innych instytucji finansowych. Ustawa z dnia 4 września 1997 r. o działach administracji rzadowej, DzU 1999, 
którą stanowi instytucja finansowa. Można zauważyć, że prawodawca wspólnotowy wyróżnia instytucje finansowe w szerszym i węższym sensie. W szerszym ujęciu instytucja finansowa jest pojmowana, jako podmiot świadczący usługi finansowe na zasadach rynkowych, co wskazuje, że instytucją finansową jest instytucja kredytowa, inwestycyjna, ubezpieczeniowa. W ujęciu wąskim instytucją finansową jest każdy podmiot świadczący usługi finansowe na zasadach rynkowych, który jednocześnie nie jest instytucją kredytowa, inwestycyjną lub ubezpieczeniową i który świadczy usługi finansowe objęte zasadą wzajemnego uznawania ${ }^{12}$.

Jako egzemplifikację tej dyskusji można wskazać, że np. Słowniku finansów $i$ bankowości, będącym thumaczeniem słownika angielskiego (publikowanego w Oxford University Press) zdefiniowano bank, jako instytucję komercyjną, przyjmującą depozyty i udzielającą kredyty, realizującą płatności w imieniu swoich klientów. Ponadto zwrócono uwagę, że banki „w ostatnich latach dywersyfikują zakres swojego działania, świadcząc coraz szerszy zakres usług finansowych" "13. Tymczasem w Słowniku ekonomii, pochodzącym z tego samego źródła, bank jest już określany, jako „instytucja finansowa, której działalność polega na zaciąganiu i udzielaniu pożyczek" ${ }^{\prime 4}$. Powyższe rozważania uprawniają do wniosku, że w systemie finansowym wyróżnia się różne rodzaje instytucji finansowych. Ich podział stopniowo traci na ostrości, w kontekście despecjalizacji, wyrażającej się we wzajemnym przejmowaniu funkcji i produktów oraz tworzeniu powiązań między nimi. $\mathrm{W}$ tym opracowaniu $\mathrm{w}$ celu uproszczenia prezentacji będzie stosowane określenie instytucja finansowa, również w odniesieniu do banków, chociaż autorka ma świadomość, że zgodnie z regulacjami prawnymi instytucja finansowa to podmiot niebędący bankiem ani instytucją kredytową ${ }^{15}$.

Definicje systemu finansowego, reprezentujące szeroki katalog ujęć były formułowane $\mathrm{w}$ różnych dziedzinach: ekonomii, prawie, czy finansach ${ }^{16}$. W literaturze przedmiotu popularne są definicje systemu finansowego, eksponu-

nr 82, poz. 928, ze zm. W kodeksie spółek handlowych art. 4, pkt 7 (Ustawa z 15 września 2000 r. Kodeks spótek handlowych, DzU 2000, nr 94, poz. 1037) do instytucji finansowych zaliczono: banki, fundusze inwestycyjne, towarzystwa funduszy inwestycyjnych lub powierniczych, towarzystwa emerytalne, fundusze emerytalne i domy maklerskie. E. Fojcik-Mastalska, Instytucja finansowa i instytucja kredytowa w projekcie nowelizacji Prawa bankowego, „Prawo Bankowe” 2001, nr 5, s. 22.

${ }^{12}$ F. Grzegorczyk, Pojecie instytucji kredytowej w świetle polskiego prawa, ,Zeszyty Naukowe Akademii Ekonomicznej w Krakowie" 2005, nr 690, s. 86.

${ }^{13}$ Stownik finansów i bankowości, Wydawnictwo Naukowe PWN, Warszawa 2008, s. 23-24.

${ }^{14}$ Stownik ekonomii, Wydawnictwo Naukowe PWN, Warszawa 2008, s. 18.

15 Art. 4.1, pkt 7, Ustawa z dnia 29 sierpnia 1997 prawo bankowe, DzU 1997, poz. 128, ze zm.

${ }^{16}$ A. Matysek-Jędrych, System finansowy - definicja i funkcje, „Bank i Kredyt” 2007, nr 10. 
jące w uproszczeniu ujęcie: prawne ${ }^{17}$, dynamiczne ${ }^{18}$, funkcjonalne ${ }^{19}$, własnościowe $^{20}$, strukturalne ${ }^{21}$. Szeroką definicję systemu finansowego proponuje A. Matysek-Jędrych, na podstawie przeglądu głównych podejść, wyróżnionych w badaniach systemu finansowego. Autorka w tym przypadku wskazuje na cztery najważniejsze podejścia do analizy systemu finansowego ${ }^{22}$ :

- Podejście instytucjonalne, opisowe, które powstało na gruncie instytucjonalizmu, czy neoinstytucjonalizmu ${ }^{23}$. Przedmiotem badań tego nurtu jest odniesienie do ram instytucjonalnych, norm i zasad postępowania o charakterze prawnym, społecznym i ekonomicznym. Cechę charakterystyczną stanowi w tym przypadku opis instytucji finansowych, struktur i zmian w czasie, ocena konkurencji, otwartości na udział kapitału zagranicznego, ochrony inwestorów i jakości regulacji, czy nadzoru. Stosowane metody w tym podejściu to: opis, klasyfikacja $\mathrm{i}$ analiza statystyczno-empiryczna. W ramach podejścia instytucjonalnego wykorzystuje się określenie instytucja finansowa ${ }^{24}$.

- Podejście eksponujące pośrednictwo, w którym zwraca się uwagę na funkcję monetarną, czyli zaopatrywanie gospodarki w pieniądz, mechanizmy powodujące krążenie siły nabywczej, współtworzenie i przepływ strumieni pieniężnych, realizowane przede wszystkim przez bank centralny i system banków komercyjnych ${ }^{25}$. W podejściu analitycznym do problematyki systemu finansowego $\mathrm{z}$ naciskiem na pośrednictwo i transformację (kwot, terminu, ryzyka) szczególną uwagę przywiązuje się do tych funkcji (pośrednictwa) i problemów wynikających $\mathrm{z}$ asymetrii informacji ${ }^{26}$. W tym podejściu analizuje się również

${ }^{17}$ System finansowy to zespót instytucji prawnych połączonych w sposób: celowy i logiczny w całość, którego zadaniem jest gromadzenie środków pieniężnych i ich rozdysponowanie. G. Krasowska-Walczak, Finanse publiczne, WSB, Poznań 1996, s. 21.

${ }^{18}$ System finansowy to mechanizm krążenia strumieni pieniężnych (współtworzenia) i przepływu siły nabywczej (między poszczególnymi uczestnikami rynku w gospodarce).

${ }^{19}$ System finansowy realizuje funkcje: tworzenie obiegu pieniężnego, zapewnienie płynności w gospodarce, pośredniczenie w przepływie strumieni finansowych, dokonywanie zamiany oszczędności na inwestycje oraz kontrola i monitorowanie podmiotami niefinansowymi. B. Pietrzak, Z. Polański, B. Woźniak (red.), op. cit., s. 17-21.

${ }^{20} \mathrm{~W}$ ujęciu własnościowym wyróżnia się przede wszystkim rynkowy i publiczny system finansowy. B. Pietrzak, Z. Polański, B. Woźniak (red.), op. cit., s. 20-56.

${ }^{21}$ System finansowy składa się z takich elementów jak: rynki, instrumenty, instytucje i zasady ich działania. B. Pietrzak, Z. Polański, B. Woźniak (red.), op. cit., s. 20.

${ }^{22}$ A. Matysek-Jędrych, op. cit.

${ }^{23}$ E. G. Furubotn, R. Richter, The New Institutional Economics - A Different Approach to Economic Analysis, „Economic Affairs” 2008, vol. 28, issue 3, September, DOI: 10.1111/j.14680270.2008.00839.x., Business Source Complete [dostęp: 7.11.2015].

${ }^{24}$ R. H. Schmidt, M. Tyrell, op. cit., s. 6.

25 A. Matysek-Jędrych, op. cit., s. 40; R. Karkowska, Teoria i funkcje systemu finansowego w kontekście narastającego ryzyka niestabilności, „Zarządzanie i Finanse” 2012, R. 10, nr 2, cz. 1, s. 100, http://bazekon.icm.edu.pl/bazekon/element/bwmeta1.element.ekon-element-000-171238395.

${ }^{26}$ A. Matysek-Jędrych, op. cit., s. 40. 
sektor instytucji niefinansowych i akceptuje zależność, zgodnie z którą lepszy system finansowy zapewnia więcej pośrednictwa ${ }^{27}$.

- Podejście funkcjonalne, którego autorzy akcentują raczej funkcje niż instytucje systemu finansowego, argumentując, że „funkcje są bardziej stabilne niż instytucje finansowe, a formy instytucjonalne sa bezpośrednia konsekwencją funkcji wypełnianych przez system finansowy"28. Według tego podejścia najważniejszą funkcją systemu finansowego jest efektywna alokacja zasobów, oparta na systemie bankowym lub rynku finansowym ${ }^{29}$. Biorąc pod uwage sposoby przepływu środków pieniężnych $\mathrm{w}$ ramach finansowania bezpośredniego poprzez rynek finansowy i pośredniego $\mathrm{z}$ udziałem pośredników finansowych można wyróżnić dwa związane $\mathrm{z}$ tym modele systemu finansowego: anglosaski model zorientowany rynkowo oraz kontynentalny model, zwany także niemiecko-japońskim, z dominacją systemu bankowego ${ }^{30}$. Charakter polskiego systemu finansowego jest zbieżny z modelem kontynentalnym. W tym systemie, właściwym również dla Włoch, Hiszpanii, Portugalii, czy Francji, dominującymi podmiotami na rynkach finansowych są banki. Natomiast w anglosaskim modelu systemu finansowego duże znaczenie mają różnego rodzaju fundusze i wyspecjalizowane banki inwestycyjne ${ }^{31}$.

- W podejściu systemowym, badany jest ,uporządkowany zespół komplementarnych (wzajemnie się wzmacniających) i możliwie spójnych elementów" ${ }^{\prime 32}$. Przedmiotem analiz zgodnie $\mathrm{z}$ tą perspektywą są zależności między poszczególnymi elementami i ich wpływ na system finansowy jako całość.

Na podstawie analizy podejść do postrzegania systemu finansowego A. Matysek wskazuje na występowanie dwóch zasadniczych kierunków: podkreślania aspektów strukturalno-instytucjonalnych (podejście instytucjonalne i systemowe) oraz podkreślenia realizacji określonych funkcji (podejście monetarne, oparte na pośrednictwie i funkcjonalne). Powyższa autorka (A. Matysek) definiuje system finansowy jako całość, złożoną ze wzajemnie powiązanych instytucji finansowych, rynków finansowych, elementów infrastruktury, dzięki której sfera realna jest adresatem określonych działań: pozyskuje fundusze, inwestuje oszczędności i zaspakaja inne potrzeby finansowe ${ }^{33}$. Taka definicja ze względu na jej szeroki zakres zostaje przyjęta do analizy etyki finansów w niniejszym opracowaniu.

${ }^{27}$ R. H. Schmidt, M. Tyrell, op. cit., s. 12.

${ }^{28}$ A. Matysek-Jędrych, op. cit., s. 41.

${ }^{29}$ R. Levine, Financial Development and Economic Growth: Views and Agenda, „Policy Research Working Paper" 1996, no. 1678, October, The World Bank, Washington, D.C., http://ssrn.com/abstract=604955 [dostęp: 5.11.2015], s. 6.

${ }^{30}$ T. Kozłowski, Problem struktury systemu finansowego $w$ kontekście relacji pomiędzy przedsiębiorstwami niefinansowymi i sektorem finansowym, „Bank i Kredyt” 2007, styczeń.

${ }^{31}$ Wł. L. Jaworski, Z. Zawadzka (red.), Bankowość. Podręcznik akademicki, Poltext, Warszawa 2006, s. 30-31.

${ }^{32}$ A. Matysek-Jędrych, op. cit., s. 41.

${ }^{33}$ Ibidem. 
Kolejny wątek badawczy łączący się z finansami to ich funkcje. Pojawienie się problematyki funkcji systemu finansowego było spowodowane włączeniem do analiz kwestii niedoskonałości rynku finansowego z jego konsekwencjami w postaci asymetrii informacji ${ }^{34}$, czy kosztów transakcyjnych ${ }^{35}$. Identyfikacją funkcji systemu finansowego zajmowało się wielu autorów ${ }^{36}$, którzy spośród szerokiej palety wymieniali zwłaszcza funkcje: monetarną, dystrybucyjną, alokacyjną i kontrolną. W ramach funkcji systemu finansowego istotną jest jego oddziaływanie na gospodarkę i wpływ na rozwój gospodarczy.

Powszechnie uważa się, że system finansowy jest niezwykle ważny dla funkcjonowania gospodarki, co ma ilustrować porównywanie go do krwioobiegu, czy lokomotywy wzrostu gospodarczego ${ }^{37}$. Opinie ekonomistów na temat powiązań między systemem finansowym a wzrostem gospodarczym i charakterem istniejącego między nimi związku przyczynowo-skutkowego są zróżnicowane. Występują zarówno zwolennicy braku zależności miedzy systemem finansowym i gospodarką, zwolennicy wpływu gospodarki realnej na system finansowy, jak i zwolennicy wpływu systemu finansowego na gospodarkę real$\mathrm{ną}^{38}$. W badaniach autorzy podkreślali dodatni, długookresowy związek między rozwojem systemu finansowego a wzrostem gospodarczym ${ }^{39}$. Wskazywano, że rola systemów finansowych i ich znaczenie rośnie poprzez oddziaływanie rozwoju systemu finansowego na wzrost gospodarczy, na przykład wpływa na wzrost wydajności ${ }^{40}$. Zakładano, że ten pozytywny wpływ na wzrost gospodarczy jest widoczny w długim okresie ${ }^{41}$.

${ }^{34}$ R. Levine, Financial Development..., 1996; R. Levine, More on Finance and Growth: More Finance, More Growth?, „Federal Reserve Bank of St. Louis Review”, 2003, vol. 85, no. 4, July-August, s. 31-46.

${ }^{35}$ O. E. Williamson, S. Masten, The Economics of Transaction Costs, Edward Elgar Publishing, Northhampton (MA) 1999.

36 R. C. Merton, Z. Bodie, A Conceptual Framework for Analyzing the Financial Environment, [w:] D. B. Crane [et al.] (red.), The Global Financial System: A Functional Perspective, Harvard Business School Press, Boston 1995, s. 7-10; R. Levine, Financial Development..., 1996; M. Wypych, Finanse $i$ instrumenty finansowe, Społeczna Wyższa Szkoła Przedsiębiorczości i Zarządzania, Łódź 2001, s. 29; B. Pietrzak, Z. Polański, B. Woźniak (red.), op. cit., s. 17-20; A Reformed Financial Sector for Europe, Commission Staff Working Document, European Commission, Brussels, 15 May 2014, COM(2014) 279 final, s. 23-24.

${ }^{37}$ S. Flejterski, $W$ poszukiwaniu nowego paradygmatu zarzadzania przedsiębiorstwami bankowymi, [w:] A. Panasiuk, K. Rogoziński (red.), Zarządzanie organizacjami ustugowymi, „Zeszyty Naukowe Uniwersytetu Ekonomicznego w Poznaniu" 2009, nr 145.

${ }^{38}$ L. Balcerowicz, Rozwój system finansowego, ,Bezpieczny Bank” 2005, nr 4, s. 125; R. de Haas, Law, Finance and Growth during Transition: A Survey, „De Economist” 2004, vol. 152, no. 3, s. 393.

${ }^{39}$ R. Levine, Financial Development..., 1996.

${ }^{40}$ Finance for Growth - Policy Choices in a Volatile World, A World Bank Policy Research, Report, Bank Światowy, kwiecień 2001.

${ }^{41}$ J. A. Lopez, M. Spiegel, Financial Structure and Macroeconomic Performance over the Short and Long Run, Federal Reserve Bank of San Francisco, Pacific Basin Working Paper Series, 02-05 September 2002. 
Kryzys na rynkach finansowych (2008) wywołał wątpliwości, co do pozytywnego wpływu systemu finansowego na gospodarkę, stanowił również inspirację do refleksji i przemyśleń nad tymi relacjami. Do systemu finansowego odnoszono się w dokumentach Komisji Europejskiej. W ramach programu reform KE wskazywano, że należy zbudować system finansowy, który będzie służył gospodarce i umożliwiał zrównoważony wzrost gospodarczy ${ }^{42}$, ponieważ przyjmowane założenia teoretyczne i wyniki badań empirycznych ${ }^{43}$, znajdujące odbicie w dokumentach i regulacjach ${ }^{44}$ wskazywały, że dobrze funkcjonujący system finansowy powinien wspierać przebieg procesów i rozwój gospodar$\mathrm{czy}^{45}$. W związku z rolą systemu finansowego wobec gospodarki w rozważaniach autorów pojawił się problem finansjalizacji (finansyzacji). Nazwa tej koncepcji wywodzi się od thumaczenia angielskiego wyrazu financialization. W definicjach wyjaśniających specyfikę tego pojęcia podkreśla się szczególną i rosnącą rolę sfery finansowej i kryteriów finansowych w funkcjonowaniu gospodarki $^{46}$. Finansjalizacja jest określana, jako długookresowa tendencja zmiany roli systemu finansowego $\mathrm{w}$ gospodarce ${ }^{47}$, czy radykalny wzrost znaczenia sektora finansowego w działalności gospodarczej ${ }^{48}$, również jako dominacja sfery finansowej nad sferą realną oraz jako wpływanie elit finansowych na procesy gospodarowania na poziomie mikro i makroekonomicznym ${ }^{49}$. Idea finansyzacji polega na tym, że właściciele instytucjonalni ze sfery finansowej poszukują zysków w krótkim okresie (stąd rozwój innowacji finansowych, m.in. instrumentów pochodnych, inżynierii finansowej). Dążenie do skracania czasu inwestycji powoduje skupienie na krótkookresowej zyskowności, a nie na stabilności roz-

${ }^{42}$ A Reformed Financial Sector for Europe...

${ }^{43}$ Zob. szerzej: R. Levine, Financial Development and Economic Growth: Views and Agen$d a$, „Journal of Economic Literature” 1997, vol. XXXV, June; M. Bijlsma, A. Dubovik, Banks, Financial Markets and Growth in Developed Countries. A Survey of the Empirical Literature, „CPB Discussion Paper” 2014, no. 266, February.

${ }^{44}$ Według opinii Komisji Europejskiej, podsumowującej reformy sektora finansowego celem systemu finansowego powinno być służenie gospodarce i zrównoważonemu wzrostowi gospodarczemu. A Reformed Financial Sector for Europe..., s. 22.

${ }^{45}$ Dobrze funkcjonujący system finansowy powinien realizować swoje funkcje, takie jak: wymianę wartości, pośrednictwo, transfer ryzyka, płynność, A Reformed Financial Sector for Europe..., s. 23-24, B. Pietrzak, Z. Polański, B. Woźniak (red.), op. cit., s. 17-20.

${ }^{46}$ G. Epstein, Financialization, Rentier Interests, and Central Bank Policy, Department of Economics and Political Economy Research Institute (PERI), University of Massachusetts, Amherst, December 2001, s. 2-3.

${ }^{47}$ M. Ratajczak, Finansyzacja gospodarki, „Ekonomista” 2012, nr 3, s. 282.

${ }^{48}$ W. Małecki, Przemiany sektora bankowego i ich konsekwencje, ,Ekonomista” 2014, nr 4 , s. 468.

${ }^{49}$ M. Ratajczak, op. cit., s. 283; P. Marszałek, Finansyzacja w Polsce - ciekawostka teoretyczna czy realny problem, „Prace Naukowe Uniwersytetu Ekonomicznego we Wrocławiu” 2013, nr 306, s. 236. 
woju $^{50}$. Ostatnio (2012) zauważono, że pozytywny wpływ rozwoju rynku finansowego na wzrost gospodarczy jest widoczny do określonego poziomu wskaźnika kredytu w relacji do PKB, powyżej tego poziomu nie tylko nie występuje wpływ pozytywny, ale także powyższy wpływ ma charakter negatywny ${ }^{51}$. Takie wnioski wynikają z badań M. Pagano i G. Pica ${ }^{52}$, czy badań J. L. Arcand, E. Berkes i U. Panizza ${ }^{53}$. Wyjaśniając negatywny wpływ wielkości systemu bankowego na sferę realną M. Pagano podkreślał, że: nadmierna ekspansja sektora bankowego powoduje nieprawidłową alokację kapitału finansowego i ludzkiego, a w przypadku większych systemów bankowych występuje tendencja do doświadczania bardziej poważnych kryzysów finansowych ${ }^{54}$.

W Polsce następuje stopniowe powiększanie rozmiarów systemu finansowego, o czym świadczy rosnący poziom wskaźnika aktywów systemu finansowego w relacji do PKB, przy czym poziom tego wskaźnika w Polsce jest niższy niż w Czechach, na Węgrzech czy w strefie euro, ale wykazuje najwyższą spośród badanych dynamikę wzrostu (w 2014 r. wobec 2003 r. dynamika wzrostu aktywów wynosiła $155 \%$ ) (zob. tab. 1).

Tabela 1. Aktywa systemu finansowego w relacji do PKB w wybranych krajach Europy Środkowo-Wschodniej oraz strefie euro w latach 2003-2014 [\%]

\begin{tabular}{|c|c|c|c|c|c|c|c|c|c|c|c|c|c|}
\hline $\begin{array}{c}\text { Wyszczegól- } \\
\text { nienie }\end{array}$ & 2003 & 2004 & 2005 & 2006 & 2007 & 2008 & 2009 & 2010 & 2011 & 2012 & 2013 & 2014 & $* \%$ \\
\hline \hline Polska & 78,5 & 78,6 & 85,0 & 96,5 & 103,1 & 110,3 & 111,0 & 116,2 & 116,4 & 121,2 & 125,9 & 121,4 & 154,6 \\
\hline Czechy & 114,7 & 119,3 & 126,7 & 125,6 & 134,3 & 137,3 & 138,4 & 140,7 & 147,0 & 153,3 & 165,0 & 164,4 & 143,3 \\
\hline Węgry & 99,3 & 100,0 & 114,9 & 128,5 & 141,4 & 152,3 & 165,0 & 168,8 & 148,6 & 135,1 & 132,9 & 133,3 & 134,2 \\
\hline Strefa euro & 351,2 & 365,7 & 398,4 & 416,4 & 435,8 & 461,2 & 481,7 & 493,6 & 481,5 & 487,1 & 470,6 & 493,8 & 140,6 \\
\hline
\end{tabular}

* Dynamika wzrostu w 2014 r. wobec roku bazowego 2003 [w \%]

Źródło: Rozwój systemu finansowego w Polsce w 2006 r., NBP, Warszawa 2007, s. 13; Rozwój systemu finansowego w Polsce w 2006 r., NBP Warszawa 2007, s. 13; Rozwój systemu finansowego $w$ Polsce w 2007 r., NBP Warszawa 2008, s. 13; Rozwój systemu finansowego w Polsce $w 2013$ r, NBP, Warszawa 2014, s. 22; Rozwój systemu finansowego w Polsce w 2014 r, NBP, Warszawa 2015, s. 12 oraz obliczenia własne.

${ }^{50}$ S. Lanza, M. Calcaterrra, F. Perrini, Etyka, finanse a wartość przedsiębiorstwa, Fundacja na rzecz Polskich Związków Kredytowych - Instytut Stefczyka, Sopot 2010, s. 108.

${ }^{51}$ Is Europe Overbanked?, ESRB Advisory Scintific Committee (chaired by Marco Pagano), mBank-CASE Seminar Proceedings no. 132/2014, s. 29.

52 M. Pagano, G. Pica, Finance and Employment, „Economic Policy” 2012, vol. 27(69), s. 5-55, http://www.igier.unibocconi.it/files/finance_employment.pdf.

${ }^{53}$ J. L. Arcand, E. Berkes, U. Panizza, Too Much Finance?, 2012, http://graduateinstitute.ch/ webdav/site/cfd/shared/docs/abp_sept2012.pdf.

${ }^{54}$ Is Europe Overbanked?..., s. 32. 
Sektor bankowy to jeden z ważniejszych uczestników systemu finansowego. W Polsce, tak jak w innych krajach regionu (Czechy, Węgry, Słowacja), jest to sektor dominujący W latach 2008-2014 poziom aktywów sektora bankowego wobec PKB wynosił od 79 do $89 \%$. Udział banków w strukturze aktywów polskiego systemu finansowego w 2012 i 2013 r. wynosił ponad $67 \%^{55}$. Sektor bankowy w Polsce, pomimo dominacji w systemie finansowym w Polsce jest relatywnie niewielki wobec sektorów bankowych innych krajów UE ${ }^{56}$ (zob. tab. 2 i 3). $\mathrm{Z}$ informacji zamieszczonych w tabelach 2 i 3 wynika, że wskaźnik depozyty/PKB osiąga niższe poziomy w porównaniu do wskaźnika kredyty/PKB. $\mathrm{Z}$ kolei dynamika wzrostu depozytów była wyższa w badanym roku 2014 niż w tym samym momencie w odniesieniu do kredytów.

Tabela 2. Stopień rozwoju sektora bankowego w wybranych krajach Europy Środkowo-Wschodniej oraz w strefie euro w latach 2008-2014 [\%]

\begin{tabular}{|l|r|r|r|r|r|r|r|r|r|r|r|r|r|r|}
\hline & \multicolumn{9}{|c|}{ Aktywa/PKB } & \multicolumn{4}{c|}{ Kredyty/PKB } \\
\cline { 2 - 14 } & 2008 & 2009 & 2010 & 2011 & 2012 & 2013 & 2014 & 2008 & 2009 & 2010 & 2011 & 2012 & 2013 & 2014 \\
\hline \hline Polska & 81,5 & 78,9 & 81,8 & 83,3 & 83,5 & 84,5 & 88,5 & 46,5 & 46,7 & 49,2 & 51,4 & 50,0 & 50,3 & 51,6 \\
\hline Czechy & 109,1 & 112,9 & 114,2 & 117,1 & 116,0 & 129,4 & 131,0 & 52,2 & 53,9 & 54,7 & 54,9 & 58,3 & 64,7 & 66,4 \\
\hline Węgry & 109,1 & 111,3 & 103,7 & 104,2 & 110,1 & 104,4 & 102,7 & 54,2 & 52,5 & 52,0 & 50,7 & 43,1 & 39,3 & 36,7 \\
\hline $\begin{array}{l}\text { Strefa } \\
\text { euro }\end{array}$ & 333,3 & 334,6 & 338,6 & 355,8 & 334,1 & 308,3 & 309,9 & 116,6 & 119,1 & 120,5 & 105,7 & 100,0 & 97,0 & 94,2 \\
\hline
\end{tabular}

Źródło: Rozwój systemu finansowego w Polsce w 2010 r., NBP, Warszawa 2012, s. 12; Rozwój systemu finansowego w Polsce w 2013 r..., s. 24; Rozwój systemu finansowego w Polsce $w 2014$ r..., s. 15.

Tabela 3. Stopień rozwoju sektora bankowego w wybranych krajach Europy Środkowo-Wschodniej oraz w strefie euro w latach 2004-2014 [Depozyty/PKB w \%]

\begin{tabular}{|l|c|c|c|c|c|c|c|c|c|c|c|c|c|}
\hline & 2004 & 2005 & 2006 & 2007 & 2008 & 2009 & 2010 & 2011 & 2012 & 2013 & 2014 & $\mathrm{D}^{*}$ & $\mathrm{~K}^{*}$ \\
\hline \hline Polska & 32,8 & 34,0 & 35,4 & 35,6 & 38,8 & 41,7 & 43,6 & 44,8 & 44,8 & 46,6 & 49,3 & 127 & 111 \\
\hline Czechy & 55,5 & 56,1 & 60,0 & 62,8 & 62,1 & 63,9 & 65,8 & 73,6 & 70,2 & 76,9 & 79,2 & 128 & 127 \\
\hline Węgry & 32,7 & 33,8 & 35,2 & 34,4 & 36,4 & 36,5 & 34,8 & 36,0 & 34,8 & 32,4 & 31,6 & 87 & 68 \\
\hline $\begin{array}{l}\text { Strefa } \\
\text { euro }\end{array}$ & b. d. & 102,0 & 69,8 & 72,5 & 74,7 & 84,8 & 85,4 & 80,4 & 80,5 & 82,4 & 83,4 & 112 & 81 \\
\hline
\end{tabular}

D* Dynamika wzrostu depozytów w 2014 r. wobec roku bazowego 2008 [w \%].

K* Dynamika wzrostu kredytów w 2014 r. wobec roku bazowego 2008 [w \%].

Dane źródłowe tab. 2.

Źródło: Rozwój systemu finansowego w Polsce w 2004 r., NBP, Warszawa 2005, s. 15; Rozwój systemu finansowego w Polsce w 2005 r., NBP, Warszawa 2006, s. 15; Rozwój systemu finansowego $w$ Polsce $w 2006$ r..., s. 17; Rozwój systemu finansowego w Polsce $w 2008$ r., NBP, Warszawa 2009, s. 18; Rozwój systemu finansowego w Polsce w 2013 r..., s. 12; Rozwój systemu finansowego $w$ Polsce w 2014 r..., s. 15.

\footnotetext{
${ }^{55}$ Rozwój systemu finansowego w Polsce w 2013 r., NBP, Warszawa 2014, s. 24.

${ }^{56}$ Ibidem, s. 120.
} 
Pomimo konsekwencji kryzysu finansowego widocznych poza granicami Polski kondycja tego sektora jest dobra ${ }^{57}$. Jednak nie jest to stan trwały, ale dynamiczny proces. Beata Świecka porównuje zmiany na rynku finansowym do wiecznego placu budowy, zauważa, że są one w dużym stopniu rezultatem rozwoju elektronicznych kanałów dystrybucji usług finansowych. Efektami tej oraz wielu innych zmian, dotykających instytucje finansowe są wzrost świadomości klientów i powiększanie ich wymagań, dotyczących ceny, zakresu i jakości oferowanych usług ${ }^{58}$. Eksperci ankietowani w badaniu instytutu ProPublicum zwracali szczególną uwagę, że w sferze finansów potrzebne są zmiany takie, aby instytucje finansowe mogły lepiej realizować cele społeczne i gospodarcze. Jako obszar koniecznych zmian wskazywano konieczność poprawy nastawienia do klientów, unikanie wykorzystywania pozycji dominującej, marginalizowania oczekiwań klientów i nastawienie na relacje partnerskie z klientami. Negatywnie oceniane działania instytucji finansowych, etos efektywności i nadmierna orientacja na zysk, prowadzące do erozji zaufania społecznego ${ }^{59}$, będącego podstawą działalności finansowej ${ }^{60}$ powodują potrzebę zastosowania etyki w finansach.

\section{ELEMENTY PROBLEMATYKI ETYKI FINANSÓW}

Etyka finansów, jako obszar badawczy wymaga zdefiniowania przedmiotu, zakresu głównych zagadnień i identyfikacji głównych zasad. Celem etyki finansów jest moralna ocena działań podejmowanych przez podmioty aktywne na rynkach finansowych ${ }^{61}$. Jest to obszar bardzo rozległy i różnorodny, obejmujący różne działania, kłopotliwe dylematy dotyczące rynków finansowych, instytucji

${ }^{57}$ Zysk netto sektora bankowego w okresie był wysoki i co roku przekraczał 15 mld zł. Zyskowność mierzona wskaźnikami zysku do aktywów i zysku do funduszy własnych stopniowo się obniżała z powodu rosnącej skali działania, ale była wyższa niż w sektorze przedsiębiorstw niefinansowych, Rozwój systemu finansowego w Polsce w 2013 r..., s. 123-124.

58 B. Świecka, Konsument na rynku finansowych, [w:] G. Rosa (red.), Konsument na rynku ustug, C. H. Beck, Warszawa 2015, s. 201.

${ }_{59}$ Jest to termin powszechnie stosowany w ramach doktryny i orzecznictwa, ale nie został uregulowany w przepisach prawa polskiego. W uchwale z 1999 r. Sąd Najwyższy określił najważniejsze cechy instytucji zaufania publicznego, zwracając uwagę na jej związek z dobrem publicznym podlegającym szczególnej ochronie. Uchwała Izby Cywilnej SN z 30.04.1999 r., III CZP 61/98. OSNC 1999, nr 12, poz. 201. Jak zauważa D. Czarnota, banki to instytucje zaufania publicznego ze względu na poddanie ,szczegółowym regulacjom i kontroli ze strony organów państwowych", D. Czarnota, Bank jako instytucja zaufania publicznego w dobie kryzysu - mit czy rzeczywistość?, [w:] J. Cichy, I. Pyka (red.), Innowacje a wzrost gospodarczy, cz. 1, „Zeszyty Naukowe Wydziałowe Uniwersytetu Ekonomicznego w Katowicach. Studia Ekonomiczne" 2014, nr 186, s. 156.

${ }^{60}$ J. Gieorgica, Rynek finansowy: zmieniać coś czy nie, „MF Bank” 2015, czerwiec.

${ }^{61}$ A. Zadroga, Świat finansów w perspektywie etycznej, ,Rocznik Nauk społecznych” 2008, nr 3, s. 60 . 
finansowych, wykonujących operacje finansowe, wykorzystujących instrumenty finansowe, ograniczonych regulacjami występującymi w systemie finansowym. W dalszej części opracowania precyzując określenie etyka finansów zostanie wykorzystana deskrypcja etyki w finansach, co oznacza, że oba pojęcia będą traktowane tożsamo.

Zestawienie kilku definicji etyki finansów, uporządkowanych chronologicznie zawiera tab. 4.

Ich autorzy ujmują etykę finansów w kontekście moralnym, kładąc nacisk na zaufanie, w perspektywie instrumentalnej, deontologicznej, podkreślając rolę standardów moralnych w zawodzie i wskazując na dylematy moralne zachowań na różnych poziomach aktywności finansowej.

Wzrost liczby uregulowań jest $\mathrm{z}$ jednej strony niezbędny, ale może prowadzić do zmniejszenia sprawności systemu finansowego ${ }^{62}$. W takich, ściśle określonych ramach regulacyjnych rola i znaczenie etyki wydaje się problematyczne, ale zagrożenia występujące na rynku usług finansowych, zwłaszcza obsesja efektywności finansowej ${ }^{63}$, uzasadniają potrzebę przestrzegania elementarnych wartości etycznych takich jak: uczciwość i odpowiedzialność ${ }^{64}$.

Etyka ma krytyczne znaczenie dla finansów jako mniej kosztowny substytut bezpieczeństwa kontraktowego. Im bardziej można zaufać partnerom na rynku, przestrzegającym zobowiązań i wypełniającym zasady uczciwej wymiany, tym mniej środków pieniężnych trzeba wydać na pokrycie kosztów bezpośrednich lub ponosić straty na kosztach pośrednich. Przestrzeganie jednego z ważniejszych pryncypiów, którym jest uczciwość zwiększa bezpieczeństwo transakcji, obniżając tym sposobem koszty związane $\mathrm{z}$ ograniczaniem ryzyka transakcyjnego. Finanse stanowią obszar, w którym zyski z etyki mają konkretny, cenowy wymiar. Etyka sama w sobie nie jest pozbawiona kosztów. Trzeba wycenić koszty etyki w opozycji do korzyści wynikających z ochrony w ramach kontraktów finansowych ${ }^{65}$.

Drugą, istotną zasadą moralną funkcjonującą w etyce finansów, nawiązującą do metafizyki moralności i prakseologii jest odpowiedzialność. Wyjaśnienie terminu „odpowiedzialny” odnajdujemy w monografii D. Korenik pt. Odpowiedzialność banku komercyjnego. Zdaniem tej autorki, powołującej się na słowniki języka polskiego „odpowiedzialny” to ${ }^{66}$ :

${ }^{62}$ S. Lanza, M. Calcaterrra, F. Perrini, op. cit., s. 108.

${ }^{63}$ P. H. Dembinski, Finanse po zawale. Od euforii finansowej do gospodarczego tadu, Studio EMKA, Warszawa 2011, s. 147; J. M. Bonvin, P. H. Dembiński, Ethical Issues in Financila Activities, ,Journal of Business Ethics” 2002, vol. 37.

${ }^{64}$ A. Zadroga, op. cit., s. 59-60.

${ }^{65}$ J. R. Boatright, J. Peterson, Introduction: Special Issue on Finance, „Business Ethics Quarterly" 2003, vol. 13, no. 3, s. 266.

${ }^{66}$ D. Korenik, Odpowiedzialność banku komercyjnego. Próba syntezy, Difin, Warszawa 2009, s. 14. 
Tabela 4. Wybrane definicje pojęcia etyka finansów (EF)

\begin{tabular}{|c|c|}
\hline Autor & Definicja \\
\hline $\begin{array}{c}\text { John R. Boatright } \\
\text { (1999) }\end{array}$ & $\begin{array}{l}\text { EF to etyka zawodowa zajmująca się odpowiedziami na pytania dotyczącymi: } \\
\text { - standardów moralnych w tym zawodzie; } \\
\text { - rozstrzygania dylematów moralnych w działalności finansowej. } \\
\text { Zgodnie z EF dla instytucji finansowych ważna jest odpowiedzialność } \\
\text { i zaufanie. } \\
\text { Współczesną EF tworzą trzy zasadnicze poziomy i odpowiednie tematy: } \\
\text { transakcje finansowe na rynkach (zakaz sprzeniewierzania i manipulacji, } \\
\text { uczciwość, przestrzeganie umów, wpływ na społeczeństwo, zachowanie fair } \\
\text { wobec interesariuszy), relacje z klientami (rzetelna sprzedaż, postepowania } \\
\text { eliminujące oszustwa, troska o reputacje, wysoka jakość świadczonych } \\
\text { usług, podporzadkowanie interesu pracownika interesowi klienta, unikanie } \\
\text { konfliktu interesów), dylematy osobiste pracowników (dbałość o zysk firmy } \\
\text { i troska o zysk klienta, dylemat ujawniania złego zachowania, postępowanie } \\
\text { w sytuacjach występujących w krajach o różnych kulturach). }\end{array}$ \\
\hline $\begin{array}{l}\text { Konferencja } \\
\text { Episkopatu Włoch } \\
(2000)\end{array}$ & $\begin{array}{l}\text { EF stanowi etykę typu instrumentalnego lub deontologicznego. Zajmuje się } \\
\text { warunkami, które muszą być spełnione po to żeby instytucje finansów } \\
\text { wykonywały zadania, do których są przeznaczone. }\end{array}$ \\
\hline $\begin{array}{l}\text { Wojciech Gasparski } \\
\text { (2004) }\end{array}$ & $\begin{array}{l}\text { EF dotyczy czterech poziomów zachowań: indywidualnych, instytucjonal- } \\
\text { nych, korporacyjnych i globalnych. } \\
\text { EF nie ogranicza się do ukazywania znaczenia odpowiedzialności } \\
\text { i zaufania, ale tworzy szczegółowe unormowania dla poszczególnych ele- } \\
\text { mentów systemu finansowego, m.in. kodeksy. }\end{array}$ \\
\hline $\begin{array}{l}\text { Adam Zadroga } \\
\text { (2008) }\end{array}$ & $\begin{array}{l}\text { EF zajmuje się moralną oceną działań podejmowanych przez podmioty } \\
\text { funkcjonujące na rynkach finansowych, a także wskazuje na znaczenie } \\
\text { moralnie poprawnych zachowań. }\end{array}$ \\
\hline $\begin{array}{l}\text { Encyclopedia of } \\
\text { Business Ethics } \\
\text { and Society } \\
\quad(2008)\end{array}$ & $\begin{array}{l}\text { EF obejmuje normy moralne, odnoszące się do szeroko rozumianej aktyw- } \\
\text { ności finansowej. Wskazuje, że prowadzenie finansów zgodnie z zasadami } \\
\text { moralnymi jest bardzo ważne nie tylko z powodu kluczowej roli, którą } \\
\text { finanse ogrywają w sferze osobistej, ekonomicznej, politycznej i społecznej, } \\
\text { ale także z powodu możliwości ogromnych zysków finansowych, zachęca- } \\
\text { jących ludzi do działania w sposób nieetyczny. EF odgrywa istotną rolę } \\
\text { w tworzeniu regulacji prawnych, daje wskazówki postępowania dla aktyw- } \\
\text { ności w nieuregulowanych obszarach, obejmuje normy moralne. }\end{array}$ \\
\hline $\begin{array}{l}\text { Paul H. Dębiński } \\
\text { (2013) }\end{array}$ & $\begin{array}{l}\text { EF odnosi się do szeroko rozumianego zaufania: kwestii ostrożności prak- } \\
\text { tycznej, dostępu do informacji, jej przekazywania i rozumienia przez klien- } \\
\text { tów, wykorzystywania specjalistycznej wiedzy kosztem osób trzecich } \\
\text { i czerpania z tego dochodów, zaufania w ramach kontraktów powierniczych. }\end{array}$ \\
\hline
\end{tabular}

Źródło: W. Gasparski, A. Lewicka-Strzałecka, B. Rok, G. Szulczewski, Etyka w świecie finansów: pojęcia i zagadnienia, [w:] W. Gasparski (red.), Uczciwość w świecie finansów, Wydawnictwo Wyższej Szkoły Przedsiębiorczości i Zarzadzania im. Leona Koźmińskiego, Warszawa 2004, s. 22-24; A. Zadroga, Świat finansów w perspektywie etycznej, „Rocznik Nauk Społecznych” 2008, nr 3, s. 59-74; J. R. Boatright, Ethics in Finance, Blackwell Publishing, Malden (Mass) 1999; Konferencja Episkopatu Włoch - Biuro ds. Problemów Społecznych i Pracy, Etica e finanza, „Quaderni delia Segreteria CEl” 2000, nr 19, sierpień; J. R. Boatright, Finance, Ethics of, [w:] R. Kolb (red.), Encyclopedia of Business Ethics and Society, SAGE Publications, Inc 2008, s. 899-900; P. H. Dembiński, Etyka w sferze finansów, [w:] W. Gasparski (red.), Biznes, Etyka, Odpowiedzialność, Wydawnictwo Profesjonalne PWN, Warszawa 2013, s. 191-192. 
- mający świadomość konieczności odpowiadania za swoje czyny,

- taki, na którym można polegać, rzetelny,

- gotowy do ponoszenia konsekwencji za swoje postępowanie,

- mający obowiązek dopilnować czegoś,

- ponoszący winę za coś, co nie powinno się zdarzyć.

Powyższa autorka kwestię odpowiedzialności analizuje w różnych aspektach: prawnym, moralnym, makro- i mikroekonomicznym, wobec klienta czy środowiska. W etyce finansów kwestia odpowiedzialności jest odnoszona do realizowanych przez ten sektor funkcji, roli instytucji finansowej, jako przedsiębiorstwa i organizacji połączonej z różnego rodzaju interesariuszami. Współczesne instytucje finansowe stoją w obliczu dylematu, w którym kierunku podążać, czy maksymalizować efektywność, poszukiwać wysoce rentownych obszarów biznesowych, czy rezygnować ze spektakularnych zysków na rzecz zysków stabilnych, długotrwałych bez ryzykanctwa i przerzucania nadmiernego ryzyka na klientów. Odpowiedzią na te wyzwania i konsekwencje kryzysów finansowych jest koncepcja społecznej odpowiedzialności biznesu, zgodnie z którą instytucje aktywne na rynkach finansowych mają pełnić rolę komercyjną, działać w interesie swoich właścicieli-akcjonariuszy, na rzecz własnego, mikroekonomicznego interesu, którym jest przetrwanie poprzez rozwój oraz odpowiedzialność wobec pozostałych interesariuszy ${ }^{67}$. Pośrednicy finansowi świadczą na rzecz gospodarki różne funkcje. W tradycyjnym podejściu instytucjonalnym zajmują się transformacją, alokacją, dostarczaniem środków. Zgodnie z tradycyjnym paradygmatem, redukują asymetrię informacji na rynkach finansowych. Natomiast w nowszym ujęciu są to instytucje zarządzające ryzykiem, mające w tym obszarze komparatywną przewagę kosztową. Odpowiedzialność w finansach ma charakter ekonomiczny i społeczny. Odpowiedzialność w ujęciu ekonomicznym będzie występowała wtedy, gdy zostaną zapewnione sprawiedliwe korzyści ekonomiczne interesariuszom. Odpowiedzialność w ujęciu społecznym będzie wiązała się z podejmowaniem istotnych problemów społeczeństwa ${ }^{68}$.

Dla sektora finansowego ważne są nie tylko regulacje prawne, ale także zasady określone w ramach samoregulacji, ponieważ prawo bywa niewystarczające ze względu na różnorodność możliwych przypadków i uwarunkowań (uregulowania prawne są także bardziej kosztowne z ekonomicznego i społecznego punktu widzenia $^{69}$ ). Elementem etyki biznesu, również etyki finansów są kodeksy etyczne ${ }^{70}$, będące częścią programu etycznego. Program etyczny zgodnie z definicją W. Gasparskiego to: przedsięwzięcie, którego celem jest „,...uczynienie kwestii etycznych najwyższym standardem postępowania w przedsiębiorstwie”, zawierające

${ }^{67}$ D. Korenik, op. cit., s. 314-315.

${ }^{68}$ Ibidem, s. 316-320.

${ }^{69}$ S. Lanza, M. Calcaterrra, F. Perrini, op. cit., s. 109.

${ }^{70}$ I. D. Czechowska, Kodyfikacja standardów etycznych ze szczególnym uwzględnieniem kodeksów etycznych banków, „Bezpieczny Bank” 2015, nr 1(58). 
jako jeden z elementów składowych kodeks etyczny ${ }^{71}$. W literaturze przedmiotu podnoszona jest kwestia efektywności kodyfikacji zasad etycznych w postaci kodeksów etycznych. Zwraca się uwagę, że nadmiar szczegółowych procedur postępowania, eliminując etyczną refleksję, zwalnia z podejmowania samodzielnych, uzasadnionych kulturowo decyzji ${ }^{72}$.

Zakładając, że większość aktywności finansowej dotyczy kontraktów między stronami ${ }^{73}$, etyczne zasady obowiązujące $\mathrm{w}$ finansach można ograniczyć do dwóch zasadniczych i prostych reguł: rzetelności w tworzeniu umów i przestrzegania zobowiązań kontraktowych, inaczej: bądź fair przygotowując umowe $i$ dotrzymuj zawartych tam obietnic ${ }^{74}$. W literaturze przedmiotu często pojawia się porównanie ekonomii do „nauki moralnej”. A. Smith, autor wyznaczającej początek ekonomii klasycznej „biblii ekonomii liberalnej” (która ukazała się w 1776 r. pod tytułem Badania nad natura i przyczynami bogactwa narodów) wykładał filozofię moralną. Adam Smith i jego zwolennicy określali ekonomię jako naukę moralną, ponieważ zajmowała się istotami moralnymi - ludźmi i analizowała odniesienia do moralności ${ }^{75}$. Ponadto A. Smith określał pożądane zachowanie uczestników rynku, mające charakter społeczny, ukształtowane na podstawie zwyczajów społecznych, norm i wartości moralnych ${ }^{76}$.

Etyka finansów pojawiała się również $\mathrm{w}$ ramach chrześcijańskiej refleksji moralnej, np. w odniesieniu do zawodu kupieckiego, poprzez zakaz lichwy i pożyczania na procent ${ }^{77}$, czy wskazywanie społecznego pożytku $\mathrm{z}$ handlu, zwrotu z tytułu pożyczki i produktywności pieniądza. Przedmiotem kościelnej etyki finansów były: oszustwo w umowach, kradzież, rabunek, lichwa, rzadko wyzysk biednych ${ }^{78}$. Finanse pojawiły się w takich dokumentach jak: Etica e finanza (2000) oraz Finania internetionalee agire morale $(2004)^{79}$. W powyższych dokumentach analizowano etyczne zasady w finansach nawiązując m.in.

${ }^{71}$ W. Gasparski, Kodeksy i programy etyczne, [w:] W. Gasparski (red.), Biznes, Etyka, Odpowiedzialność, Wydawnictwo Profesjonalne PWN, Warszawa 2013, s. 233; J. Stansbury, B. Barry, Ethics Programs and the Paradox of Control, „Business Ethics Quarterly” 2007, vol. 17, issue 2, s. 239-261.

${ }^{72}$ J. Stansbury, B. Barry, op. cit., s. 239-261.

${ }^{73}$ J. R. Boatright, J. Peterson, op. cit., s. 265.

${ }^{74}$ J. R. Boatright, Finance Ethics. Critical Issues..., s. 900.

${ }^{75}$ M. Zięba, OP Wstęp, [w:] J. G. Hulsmann, Etyka produkcji pieniądza, Instytut Ludwiga von Misesa, Warszawa 2014, s. IX, XXII.

${ }^{76}$ A. Smith, Theory of Moral Sentiments, Prometheus Books, New York 2000, [w:] H. J. Blommstein, Why is Ethics Not Part of Modern Economics and Finance? A Historical Perspective, „Finance \& The Common Good/Bien Commun” 2006, no. 24, Spirng/Summer, s. 54.

${ }^{77}$ J. H. de Soto, Pieniadz, kredyt bankowy i cykle koniunkturalne, Instytut Ludwiga von Misesa, Warszawa 2011, s. 47-50, 63.

${ }^{78}$ O. Bazzichi, op. cit., s. 557-571.

${ }^{79}$ Konferencja Episkopatu Włoch - Biuro ds. Problemów Spolecznych i Pracy, Etica e finan$z a$, „Quaderni delia Segreteria CEl” 2000, nr 19, sierpień, a także Finania internarionale e agire morale, „Quaderni delia Segreteria CEl” 2004, nr 2, styczeń. 
do międzynarodowego rynku finansowego i instrumentów finansowych oraz działań jednostkowych i zbiorowych ${ }^{80}$.

Główne zagadnienia etyczne związane z finansami pojawiają się na różnych poziomach: rynków finansowych, relacji instytucji finansowych z klientami, zarządzania finansami ${ }^{81}$. Często występujące problemy o charakterze etycznym w odniesieniu do rynków finansowych to: nieuczciwe praktyki rynkowe, zwłaszcza oszustwa (nadużycia) i manipulacje, nierówne warunki konkurencji, siły przetargowej, zasobów, problemy w tworzeniu, interpretacji, przestrzeganiu egzekwowaniu umów, asymetria informacji, konflikt interesów. W ramach relacji instytucji finansowych z klientami obecne są problemy o charakterze etycznym dotyczące: odpowiedzialności rzetelnej sprzedaży lub kupna, oszustwa, budowania reputacji, jakości świadczonych usług, relacji między interesem pracownika i interesem klienta, konfliktu interesów. Natomiast podmioty zaangażowane na rynkach finansowych dotykają takie problemy natury moralnej jak: dylemat między zyskiem firmy a interesem ekonomicznym klienta, problem ujawniania złego zachowania whistleblowing, postępowanie w sytuacjach podobnych, ale w krajach o różnych kulturach facilitaing money.

W. Gasparski analizując etykę biznesu zwraca uwagę na cztery poziomy uprawiania działalności gospodarczej, które można również odnieść do etyki finansów, są to: poziom podstawowy, czyli zachowań indywidualnych, poziom centralny, inaczej mezo, odnoszący się do zachowań instytucjonalnych, poziom systemu gospodarczego, czyli zachowań korporacyjnych oraz poziom zachowań globalnych ${ }^{82}$. W przypadku pierwszego poziomu, etyka finansów dotyczy indywidualnej odpowiedzialności pracowników-specjalistów danego sektora finansów: pracownika banku, firmy ubezpieczeniowej, maklera giełdowego, czy menedżera finansowego firmy. Zachowania instytucjonalne występują w obrębie określonych podmiotów sektora finansowego takich jak: banki, firmy ubezpieczeniowe, giełdy, ale także nadzorcy, organizatorzy i instytucje pomocnicze tego sektora. Natomiast poziom systemu dotyczy korporacji, czy rynków. W tym przypadku problemy etyczne wynikają $\mathrm{z}$ korporacyjnej formy organizacji, w ramach której prezesi spółek działają w interesie akcjonariuszy. Na tym poziomie stosunki z interesariuszami regulowane są poprzez corporate governance. Poziom globalny, odpowiadający nie tylko skali międzynarodowej, ale także „traktowaniu globu ziemskiego, jako jednego rynku" ${ }^{83}$ wywołuje takie problemy

${ }^{80}$ Konferencja Episkopatu Włoch...

${ }^{81}$ W. Gasparski, A. Lewicka-Strzałecka, B. Rok, G. Szulczewski, Etyka w świecie finansów: pojęcia i zagadnienia, [w:] W. Gasparski (red.) Uczciwość w świecie finansów, Wydawnictwo Wyższej Szkoły Przedsiębiorczości i Zarządzania im. Leona Koźmińskiego, Warszawa 2004, s. $24-25$.

${ }^{82}$ W. Gasparski, Etyka biznesu, [w:] W. Gasparski (red.), Biznes, etyka, odpowiedzialność, Wydawnictwa Profesjonalne PWN, Warszawa 2013, s. 80-84; J. R. Boatright, J. Peterson, op. cit., s. 266.

${ }^{83}$ W. Gasparski, Etyka ..., s. 82. 
etyczne jak: równowaga między rozwiniętymi krajami Północy a ubogimi krajami Południa ${ }^{84}$.

Zainteresowanie etyką $\mathrm{w}$ finansach wzrosło $\mathrm{w}$ związku z konsekwencjami kryzysu finansowego, który rozpoczął się w 2007 r. Powszechny jest pogląd, że to właśnie instytucje finansowe, przez swoich pracowników, zarządy i właścicieli odegrały rolę w wywołaniu globalnego kryzysu finansowego ${ }^{85}$. Przyczynami globalnego kryzysu finansowego stało się nieprzestrzeganie standardów etycznych. Jak zauważa S. Flejterski, towarzyszem bankructwa finansowego stało się bankructwo intelektualne ${ }^{86}$. Kryzys zaufania wobec systemu finansowego był konsekwencją skandali ${ }^{87}$, m.in. oszustw finansowo-księgowych ${ }^{88}$. Wiedza naukowa pozyskana w świetle badań empirycznych na temat skłonności do zachowań nieetycznych sektora bankowego (finansowego) została wzbogacona np. poprzez raport Transparency International Transparency in corporate reporting assessing the worlds largest companies ${ }^{89}$. Na podstawie tych badań R. Posner i G. Becker rozważali kwestię skłonności do zachowań nieetycznych sektora bankowego ${ }^{90}$. Brak przestrzegania podstawowych wartości etycznych powoduje zagrożenie utraty zaufania do sektora. Cechą charakterystyczną usług finansowych powiązanych z przepływem kapitału i płatnościami, o jakości nie oczywistej nawet po konsumpcji, jest zaufanie ${ }^{91}$.

Autorytet w dziedzinie etyki finansów P. H. Dembiński zwraca uwagę, że w przypadku transakcji finansowych, dotyczących wymiany aktywów finansowych na pieniądz, zaufanie występuje na dwóch poziomach. Poziom zaufania publicznego odnoszący się do środków płatniczych (pieniądza) i poziom zaufania prywatnego odnoszący się do aktywów. Działalność finansowa obejmuje realizację usług na rynku finansowym, stanowiących istotę transakcji, które

${ }^{84}$ J. R. Boatright, J. Peterson, op. cit., s. 266.

${ }^{85}$ A. van Hoorn, The Global Financial Crisis and the Values of Professionals in Finance: An Empirical Analysis, „Journal of Business Ethics” 2015, vol. 130, s. 253-269.

${ }^{86}$ S. Flejterski, op. cit., s. 109-120. Podobne konkluzje prezentuje E. Miklaszewska, która zauważa, że kryzys dotyczy również: przywództwa, moralności i odpowiedzialności, E. Miklaszewska, Globalny kryzys finansowy a perspektywy polskiej bankowości: poprawna diagnoza warunkiem skutecznej polityki publicznej, [w:] J. Szambelańczyk (red.), Globalny kryzys finansowy $i$ jego konsekwencje $w$ opiniach ekonomistów polskich, Związek Banków Polskich, Warszawa 2009, s. 62.

${ }^{87}$ S. Lanza, M. Calcaterrra, F. Perrini, op. cit., s. 107; zob. P. Masiukiewicz, Piramidy finansowe, Wydawnictwo Naukowe PWN, Warszawa 2015.

${ }^{88}$ Cykliczne raporty Association of Certified Fraud Examiners, np: Raport to the Nations in Occupational Fraud and Abuse, 2014, Global Fraud Study; P. Gut, Kreatywna księgowość a fatszowanie sprawozdań finansowych, C. H. Beck, Warszawa 2006.

${ }^{89}$ Transparency in Corporate Reporting Assessing the Worlds Largest Companies, http://www.trans-parency.org/whatwedo/publication/transparency_in_corporate_reporting_assessing the_worlds_largest_companies.

${ }^{90} \mathrm{http}: / /$ www.becker-posner-blog.com/.

${ }^{91}$ B. Świecka, op. cit., s. 200. 
w przypadku zobowiązań podlegają rozwiązaniu. Zdaniem P. H. Dembińskiego, istotą tej działalności jest określony horyzont czasowy, realizacja w przyszłości. Działalność finansowa to „handel obietnicami”. Celem transakcji finansowych jest „zmniejszenie czy skanalizowanie” niepewności występującej w przyszłości. Dla sprawnego funkcjonowania aktywów finansowych potrzebny jest sprawnie działający system „dostępu do zdarzeń przeszłych” w postaci ksiąg katastralnych, rejestrów notarialnych, poświadczający występowanie określonych przesłanek powstania transakcji finansowych, np. stanów majątkowych nieruchomości. Różnego rodzaju regulacje stanowią jedynie nośnik, a nie źródło zaufania. Działalność finansowa ma przede wszystkich charakter niematerialny, dlatego zaufanie występuje w płaszczyźnie międzyludzkiej. Poziom zaufania społecznego, ważnego z punktu widzenia etyki, będzie zależał od wartości moralnych, akceptowanych postaw etycznych, aparatu prawno-instytucjonalnego, sankcjonującego zachowania nadużywające zaufanie. Zaufanie jest ciągłym, ewoluującym procesem wpływającym na system finansowy, stanowi część kapitału społecznego, pozwalającego na utrzymywanie kosztów transakcyjnych na odpowiednio niskim poziomie, stanowi zatem ,niezbędną siłę napędową działalności finansowej". Zadaniem etyki natomiast jest utrzymywanie i podnoszenie zaufania społecznego ${ }^{92}$. Zaufanie stanowi esencję finansów, ale etyka finansów jest czymś więcej niż zaufaniem ${ }^{93}$.

\section{PODSTAWY TEORETYCZNE FINANSÓW ODNOSZĄCE SIĘ DO ETYKI}

W celu lepszego zrozumienia istoty etyki finansów, jej celów i zagadnień, warto umieścić ją w określonym etapie rozwoju teorii finansów. Ewolucją teorii finansów, którą można odnieść do etyki finansów zajmowali się różni autorzy ${ }^{94}$. Według L. San-Jose z zespołem, można wyróżnić kilka takich etapów rozwoju ${ }^{95}$. Początkowo ekonomia finansowa skupiała się na opisie fuzji i przejęć. W tym czasie, określanym jak okres klasyczny, finanse były badane w sposób opisowy. Miały wtedy miejsce dwa główne wydarzenia, powodujące zmiany: Wielka Depresja i Wojna Światowa. W badaniach finansowych koncentrowano się na upadłości, reorganizacji przedsiębiorstw, płynności finansowania i regulacjach rynków w kontekście bankructw przedsiębiorstw i rynków. Istotna ewolucja

${ }^{92}$ P. H. Dembiński, Etyka w sferze finansów, [w:] W. Gasparski (red.) Biznes, Etyka, Odpowiedzialność, Wydawnictwo Profesjonalne PWN, Warszawa 2013, s.175-177.

${ }^{93}$ J. R. Boatright, Ethics in Finance, Wiley Blackwell, Oxford 2014, s. 13.

${ }^{94}$ R. Kolb, Ethical Implications of Finance, [w:] J. Boatright, Finance Ethics: Critical Issues in Theory and Practice, John Wiley \& Sons, New Jersey 2010; M. Miller, M. Miller, The History of Finance. An Eyewitness Account, „The Journal of Portfolio Management” 2000, Summer, s. 95-101.

${ }^{95}$ San-Jose L., Retolaza J. L., Urionabarrenetxea S. [et al.], The New Paradigm of Corporate Finance: Ethics in Finance, ICTs, Financial Globalization and Stakeholder Responsibility, „International Research Journal of Finance and Economics” 2013, vol. 103, January, s. 193-194. 
w finansach rozpoczęła się od lat 50., w okresie, któremu można nadać nazwę współczesny. W owym czasie matematycy i ekonomiści, wspomagani przez zaawansowaną technologię, byli źródłem wyrafinowanych teorii finansowych i modeli prognostycznych. Obszar badawczy był zdeterminowany przez model Modiglianiego i Millera. Wraz z momentem ustalenia teorii agencji przez Jensen i Meckling w 1976 r. rozpoczął się okres, w którym w teorii finansów pojawiły się takie zagadnienia badawcze jak: prawa akcjonariuszy, wynagrodzenia prezesów, dobre praktyki. Następnym etapem wyodrębnionym w badaniach L. San-Jose z zespołem jest okres przyszły, umiejscowiony w czasie jako rozpoczynający się od XXI w. Właśnie w tym okresie obok zmian technologicznych, informatycznych, czy globalizacji pojawia się etyka finansów ${ }^{96}$.

Podejście klasyczne Podejście współczesne Podejście przyszłościowe

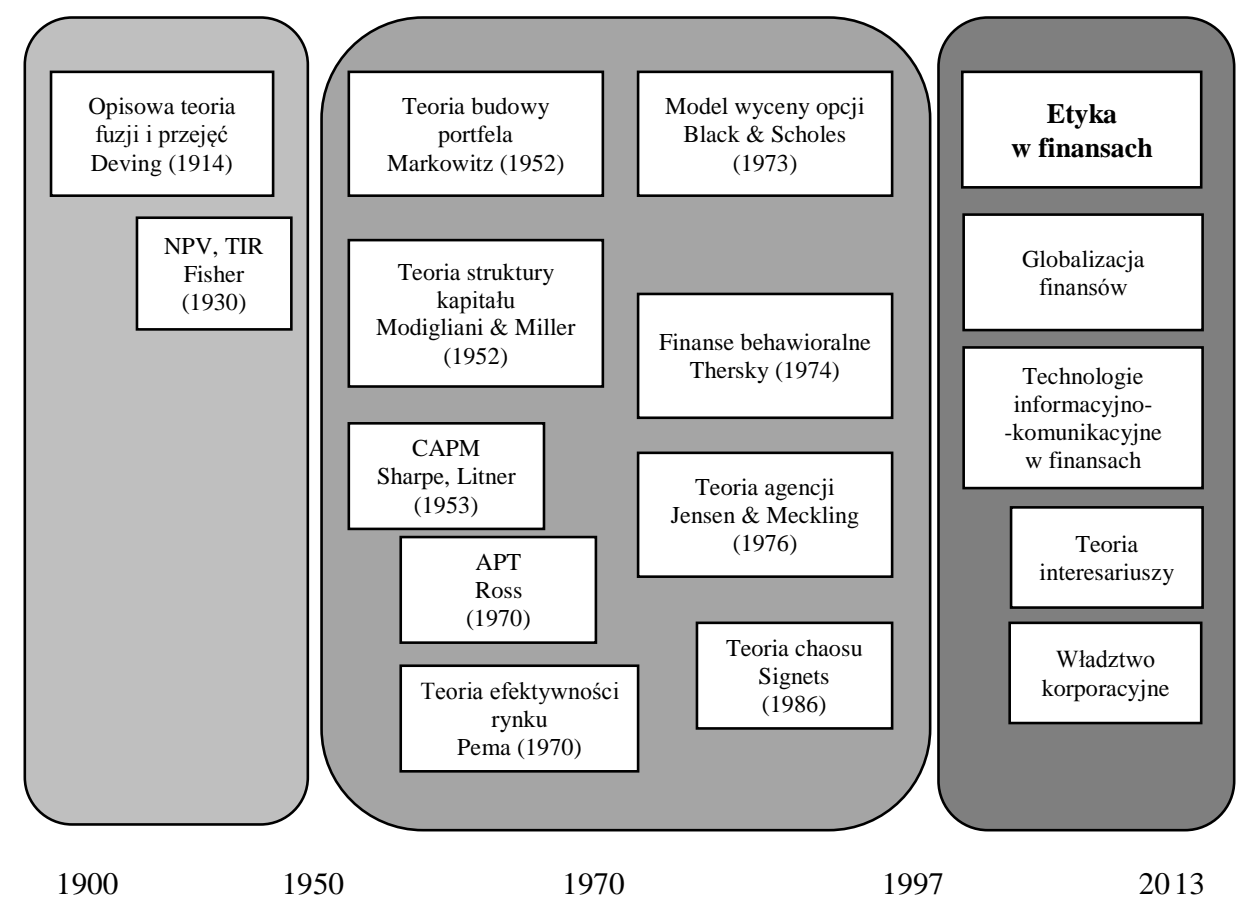

Schemat 1. Ewolucja teorii finansów - od podejścia klasycznego do przyszłościowego

Źródło: na podstawie: L. San-Jose, J. L Retolaza, S. Urionabarrenetxea [et al.], The New Paradigm of Corporate Finance: Ethics in Finance, ICTs, Financial Globalization and Stakeholder Responsibility, „International Research Journal of Finance and Economics” 2013, vol. 103, January, s. 193.

\section{${ }^{96}$ Ibidem.}


W nowoczesnej ekonomii i finansach rola etyki jest mało znacząca. W przeszłości występowały rozważania o funkcjonowaniu moralnych zasad w gospodarce. Obecnie etyka, jako taka, nie jest częścią głównych badań dotyczących efektywności czy rentowności rynków finansowych. Zagadnienia etyczne w niewielkim stopniu albo wcale nie były widoczne w badaniach nad nowoczesnymi finansami takich intelektualnych pionierów jak: Harry Markowitz, Paul Samuelson, William Sharpe, Eugene Fama, Merton Miller, Robert Merton, Fisher Black and Myron Scholes ${ }^{97}$. W obrębie modyfikacji nowej ekonomii instytucjonalnej pojawiały się odniesienia do standardów moralnych, mających wpływ na ewolucję i funkcjonowanie instytucji i rynków finansowych, ale w ramach tego podejścia zależność rentowności i efektywności rynków finansowych w powiązaniu z przestrzeganiem standardów moralnych, czy motywacją etyczną nie została zbadana i ujęta $\mathrm{w}$ formie matematyczno-ekonometrycznych modeli ${ }^{98}$. Teorie finansów ujmowały przy pomocy matematycznych funkcji maksymalizację wartości dla akcjonariuszy ${ }^{99}$. Powyższe teorie finansowe były uznane za nieodnoszące się do etyki lub etycznie neutralne ${ }^{100}$, co potwierdza J. Horrigan, który analizując teorie finansowe stwierdza, że „... świat Nowych Finansów nie jest miłym etycznie miejscem..." ${ }^{101}$. Obecnie w ramach finansów korporacji docenia się znaczenie ryzyka zarządzania i dążenie do kreacji wartości przedsiębiorstwa poprzez tworzenie wartości, zarówno dla akcjonariuszy jak i innych interesariuszy. W tym kontekście etyczne obszary, budzące większe zainteresowanie to ${ }^{102}$ :

- kreatywna rachunkowość,

- zarządzanie przychodami,

- wprowadzanie w błąd,

- wykorzystywanie informacji niejawnych,

- oszustwa i nadużycia finansowe,

- nadmiernie wysokie wynagrodzenia kadry zarządzającej,

- przekupstwo, korupcja.

Teoretyczne podstawy etyki w finansach można również odnieść do podstaw teoretycznych polityki konsumenckiej, które wynikają z niedoskonałości rynku market failures, łączących się z konkurencją, asymetrią informacji, występowaniem kosztów transakcyjnych, nieracjonalnością w zachowaniach kon-

${ }^{97}$ H. J. Blommstein, Why is Ethics Not Part of Modern Economics and Finance? A Historical Perspective, „Finance \& The Common Good/Bien Commun” 2006, no. 24, Spring/Summer, s. 56.

${ }^{98}$ Ibidem.

${ }^{99}$ L. San-Jose, J. L Retolaza, S. Urionabarrenetxea [et al.], op. cit., s. 199.

${ }^{100}$ R. Kolb, op. cit., s. 5.

${ }^{101}$ J. O. Horrigan, The Ethics of the New Finance, „Journal of Business Ethics” 1987, vol. 6, s. 107.

${ }^{102}$ L. San-Jose, J. L Retolaza, S. Urionabarrenetxea [et al.], op. cit., s. 199. 
sumentów. Istotne są także czynniki zewnętrzne oddziaływujące na rynki dóbr i usług konsumpcyjnych, również uczestników rynków finansowych, takie jak: deregulacja, globalizacja, postęp techniczny ${ }^{103}$. W przypadku osoby fizycznej - konsumenta, zwraca się uwagę na teorię niedoskonałej informacji. Zgodnie z jej założeniami, sprzecznymi wobec ekonomii neoklasycznej, nie wszystkie wybory podmiotów uczestniczących w rynku wynikają z posiadania i rozumienia pełnej informacji. Drugi, istotny nurt teorii ekonomii wykorzystywany w finansach to ekonomia behawioralna, której autorzy analizują kwestie podejmowania decyzji przez konsumentów, odrzucając założenie ekonomii neoklasycznej o racjonalności podejmowanych decyzji w kontekście realizacji własnego interesu ${ }^{104}$. Eksperymenty laboratoryjne, których celem było ustalenie okoliczności podejmowania decyzji wskazywały, że do takich uwarunkowań można zaliczyć sposób prezentowania informacji (framing), szkodliwość nadmiaru informacji (information overload), przecenianie ,własnych przyszłych możliwości i przywiązywanie większej wartości do obecnych pożytków niż przyszłych wydatków" (decyzje o skorzystaniu z kredytu). Finansowi usługodawcy nauczyli się wykorzystywać niedoskonałości behawioralne konsumentów poprzez stosowanie nielojalnych praktyk, do których należą np. oferty promocyjne obowiązujące w ograniczonym czasie, które sprawiają wrażenie ograniczoności ${ }^{105}$.

\section{PODSUMOWANIE}

W opracowaniu przedstawiono aspekty definicyjne finansów odnoszące się do systemu finansowego, jego funkcji, zwłaszcza roli pełnionej na rzecz gospodarki. Uwzględniono znaczenie głównego sektora w systemie finansowym, którym jest sektor bankowy. Ukazano również zarys problematyki etyki finansów poprzez prezentację katalogu związanych z nią zagadnień, takich jak: definiowanie, identyfikacja głównych zasad etycznych, mających znaczenie dla systemu finansowego, uczciwości i odpowiedzialności, etycznych zachowań uczestników systemu finansowego na różnych poziomach: pracownika, instytucji, korporacji, czy globalnym. Odnotowano występowanie kodeksów etyki, podkreślono kwestię budowania zaufania wśród klientów systemu finansowego, niezbędnego dla funkcjonowania instytucji finansowych, będących instytucjami zaufania publicznego. Ukazano podstawy teoretyczne finansów i ich powiązania $\mathrm{z}$ aspektami etycznymi.

W wyniku przeprowadzonej analizy można stwierdzić, że etyka finansów łączy dwa istotne obszary - etykę oraz finanse i wydaje się dla krajów o gospo-

${ }^{103}$ M. Lissowska, Polityka konsumencka - podstawy teoretyczne, cele i narzędzia, „Gospodarka Narodowa" 2010, nr 10, s. 57.

${ }^{104}$ Ibidem, s. 58-65.

${ }^{105}$ Ibidem. 
darce rynkowej nie tylko tymczasową modą, ale koniecznością. Etyka finansów umiejscawia finanse w szerokiej płaszczyźnie, pozwalającej na refleksje i naukowe poszukiwania zagadnień, problemów o charakterze: ekonomicznym, finansowym, społecznym i moralnym. W codziennych sytuacjach, także w odniesieniu do transakcji związanych z finansami, pojawiają się dylematy etyczne. Biorąc powyższe pod uwagę, warto prowadzić badania nad etyką finansów i poszukiwać odpowiedzi na pytanie czy i dlaczego standardy moralne odgrywa$\mathrm{ja} /$ powinny odgrywać istotną rolę w ewolucji finansów ${ }^{106} \mathrm{i}$ czy zamieniając etos krótkookresowej efektywności mogą wpływać na rozwój gospodarki i społeczeństwa.

Podsumowując, w niniejszym rozdziale uporządkowano istniejący stan wiedzy teoretycznej odnoszącej się do związków etyki z biznesem instytucji sektora finansowego, przedstawiono kierunki ewolucji i rozwoju tego stanu wiedzy, a także - na podstawie teoretycznych ujęć powiązań etyki z biznesem oraz rosnącego znaczenia wkładu sektora finansowego do wzrostu gospodarczego (mierzone wskaźnikami odnoszącymi się do PKB) - wskazano na silną potrzebę włączania etyki w działalność instytucji finansowych.

\section{BIBLIOGRAFIA}

Arcand J. L., Berkes E., Panizza U. Too Much Finance? 2012, http://graduateinstitute.ch/webdav/ site/cfd/shared/docs/abp_sept2012.pdf.

A Reformed Financial Sector for Europe, Commission Staff Working Document, European Commission, Brussels, 15 May 2014, COM(2014) 279 final.

Balcerowicz L., Rozwój system finansowego, „Bezpieczny Bank” 2005 , nr 4.

Bazzichi O., Etyka biznesu, „Społeczeństwo” 2004, rok XIV, nr 3.

Bijlsma M., Dubovik A., Banks, Financial Markets and Growth in Developed Countries. A Survey of the Empirical Literature, „CPB Discussion Paper” 2014, no. 266, February.

Blommstein H. J., Why is Ethics Not Part of Modern Economics and Finance? A Historical Perspective, „Finance \& The Common Good/Bien Commun” 2006, no. 24, Spring/Summer.

Boatright J. R., Ethics in Finance, Blackwell Publishing, Malden (Mass) 1999.

Boatright J. R., Ethics in Finance, Wiley Blackwell, Oxford 2014.

Boatright J. R., Finance, Ethics of, [w:] R. Kolb (red.), Encyclopedia of Business Ethics and Society, SAGE Publications, Inc., 2008.

Boatright J. R., Finance Ethics: Critical Issues in Theory and Practice, John Wiley \& Sons, New Jersey 2010.

Boatright J. R., Peterson J., Introduction: Special Issue on Finance, „Business Ethics Quarterly” 2003, vol. 13 , no. 3 .

Bonvin J. M., Dembiński P. H., Ethical Issues in Financila Activities, „Journal of Business Ethics” 2002, vol. 37.

Czarnota D., Bank jako instytucja zaufania publicznego w dobie kryzysu - mit czy rzeczywistość?, [w:] J. Cichy, I. Pyka (red.), Innowacje a wzrost gospodarczy, cz. 1, „Zeszyty Naukowe Wydziałowe Uniwersytetu Ekonomicznego w Katowicach. Studia Ekonomiczne” 2014, nr 186.

${ }^{106}$ H. J. Blommstein, op. cit., s. 63. 
Czechowska I. D., Przegląd definicji banku stanowiąego aktywny kanat dystrybucji produktów ubezpieczeniowych, ,Acta Universitatis Lodziensis. Folia Oeconomica” 2011, nr 259.

Czechowska I. D., Kodyfikacja standardów etycznych ze szczególnym uwzględnieniem kodeksów etycznych banków, „Bezpieczny Bank” 2015, nr 1(58).

De Haas R., Law, Finance and Growth during Transition: A Survey, „De Economist” 2004, vol. 152 , no. 3 .

De Soto J. H., Pieniadz, kredyt bankowy i cykle koniunkturalne, Instytut Ludwiga von Misesa, Warszawa 2011.

Dębski W., Rynek finansowy i jego mechanizmy. Podstawy teorii i praktyki, Wydawnictwo Naukowe PWN, Warszawa 2002.

Dembiński P. H., Etyka w sferze finansów, [w:] W. Gasparski (red.), Biznes, Etyka, Odpowiedzialność, Wydawnictwo Profesjonalne PWN, Warszawa 2013.

Dembinski P. H., Finanse po zawale. Od euforii finansowej do gospodarczego ładu, Studio EMKA, Warszawa 2011.

Directive 2000/12/EC of the European Parliament and the Council of 20 March 2000 Relating to Taking up and Pursuit of the Business of Credit Institutions, O. J. nr L 126, 26.05.2000.

Epstein G., Financialization, Rentier Interests, and Central Bank Policy, Department of Economics and Political Economy Research Institute (PERI), University of Massachusetts, Amherst, December 2001.

Finance for Growth - Policy Choices in a Volatile World, A World Bank Policy Research Report, Bank Światowy, kwiecień 2001.

Finania internarionale e agire morale, „Quaderni delia Segreteria CEl” 2004, nr 2, styczeń.

Flejterski S., W poszukiwaniu nowego paradygmatu zarządzania przedsiębiorstwami bankowymi, [w:] K. Rogoziński, A. Panasiuk, Zarządzanie organizacjami usługowymi, „Zeszyty Naukowe Uniwersytetu Ekonomicznego w Poznaniu" 2009, nr 145.

Fojcik-Mastalska E., Instytucja finansowa i instytucja kredytowa w projekcie nowelizacji Prawa bankowego, „Prawo Bankowe” 2001, nr 5.

Furubotn E. G., Richter R., The New Institutional Economics - A Different Approach to Economic Analysis, „Economic Affairs” 2008, vol. 28, issue 3, September, DOI: 10.1111/j.14680270.2008.00839.x., [za:] Business Source Complete.

Gasparski W., Etyka biznesu [w:] W. Gasparski (red.), Biznes, etyka, odpowiedzialność, Wydawnictwa Profesjonalne PWN, Warszawa 2013.

Gasparski W., Kodeksy i programy etyczne, [w:] W. Gasparski (red.) Biznes, etyka, odpowiedzialność, Wydawnictwo Profesjonalne PWN, Warszawa 2013.

Gasparski W., Lewicka-Strzałecka A., Rok B., Szulczewski G., Etyka w świecie finansów: pojęcia i zagadnienia, [w:] W. Gasparski (red.), Uczciwość w świecie finansów, Wydawnictwo Wyższej Szkoły Przedsiębiorczości i Zarządzania im. Leona Koźmińskiego, Warszawa 2004.

Gieorgica J., Rynek finansowy: zmieniać coś czy nie, „Miesięcznik Finansowy Bank” 2015, czerwiec.

Grzegorczyk F., Pojecie instytucji kredytowej w świetle polskiego prawa, „Zeszyty Naukowe Akademii Ekonomicznej w Krakowie" 2005, nr 690.

Gut P., Kreatywna księgowość a fatszowanie sprawozdań finansowych, C. H. Beck, Warszawa 2006.

Horrigan J. O., The Ethics of the New Finance, „Journal of Business Ethics” 1987, vol. 6.

Is Europe Overbanked?, ESRB Advisory Scintific Committee (chaired by Marco Pagano), mBankCASE Seminar Proceedings no. 132/2014.

Jaworski Wł. L., Zawadzka Z. (red.), Bankowość. Podręcznik akademicki, Poltext, Warszawa 2006.

Karkowska R., Teoria i funkcje systemu finansowego w kontekście narastajacego ryzyka niestabilności, ,Zarządzanie i Finanse” 2012, R. 10, nr 2, cz. 1, http://bazekon.icm.edu.pl/bazekon/element/ bwmeta1.element.ekon-element-000171238395. 
Kolb R., Ethical Implications of Finance, [w:] J. Boatright, Finance Ethics: Critical Issues in Theory and Practice, John Wiley \& Sons, New Jersey 2010.

Konferencja Episkopatu Włoch - Biuro ds. Problemów Społecznych i Pracy, Etica e finanza, „Quaderni delia Segreteria CEl” 2000, nr 19, sierpień.

Korenik D., Odpowiedzialność banku komercyjnego. Próba syntezy, Difin, Warszawa 2009.

Kozłowski T., Problem struktury systemu finansowego $w$ kontekście relacji pomiędzy przedsiębiorstwami niefinansowymi i sektorem finansowym, „Bank i Kredyt” 2007, styczeń.

Krasowska-Walczak G., Finanse publiczne, WSB, Poznań 1996.

Lanza S., Calcaterrra M., Perrini F., Etyka, finanse a wartość przedsiębiorstwa, Fundacja na rzecz Polskich Związków Kredytowych - Instytut Stefczyka, Sopot 2010.

Levine R., Financial Development and Economic Growth: Views and Agenda, „Policy Research Working Paper" 1996, no. 1678, October, The World Bank, Washington, D.C., http://ssrn.com/abstract=604955.

Levine R., Financial Development and Economic Growth: Views and Agenda, „Journal of Economic Literature" 1997, vol. XXXV, June.

Levine R., More on Finance and Growth: More Finance, More Growth?, „Federal Reserve Bank of St. Louis Review" 2003, vol. 85, no. 4, July-August.

Lissowska M., Polityka konsumencka - podstawy teoretyczne, cele i narzędzia, „Gospodarka Narodowa" 2010, nr 10.

Lopez J. A., Spiegel M., Financial Structure and Macroeconomic Performance over the Short and Long Run, Federal Reserve Bank of San Francisco, Pacific Basin Working Paper Series, 02-05 September 2002.

Małecki W., Przemiany sektora bankowego i ich konsekwencje, „Ekonomista” 2014, nr 4.

Marszałek P., Finansyzacja w Polsce - ciekawostka teoretyczna czy realny problem, „Prace Naukowe Uniwersytetu Ekonomicznego we Wrocławiu" 2013, nr 306.

Masiukiewicz P., Piramidy finansowe, Wydawnictwo Naukowe PWN, Warszawa 2015.

Matysek-Jędrych A., System finansowy - definicja i funkcje, „Bank i Kredyt” 2007, nr 10.

Merton R. C., Bodie Z., A Conceptual Framework for Analyzing the Financial Environment, [w:] D. B. Crane [et al.] (red.), The Global Financial System: A Functional Perspective, Harvard Business School Press, Boston 1995.

Miklaszewska E., Globalny kryzys finansowy a perspektywy polskiej bankowości: poprawna diagnoza warunkiem skutecznej polityki publicznej, [w:] J. Szambelańczyk (red.), Globalny kryzys finansowy i jego konsekwencje w opiniach ekonomistów polskich, Związek Banków Polskich, Warszawa 2009.

Miller M., The History of Finance. An Eyewitness Account, „The Journal of Portfolio Management" 2000, Summer.

Oręziak L., Rynek finansowy Unii Europejskiej, Biblioteka Bankowca, Warszawa 1999.

Pagano M., Pica G., Finance and Employment, „Economic Policy” 2012, vol. 27(69), http://www.igier.unibocconi.it/files/finance_employment.pdf.

Pietrzak B., Polański Z. (red.), System finansowy w Polsce, Lata dziewięćdziesiąte, Wydawnictwo Naukowe PWN, Warszawa 1997.

Pietrzak B., Polański Z., Woźniak B. (red.), System finansowy w Polsce, t. 1, Wydawnictwo Naukowe PWN, Warszawa 2008.

Raport to the Nations in Occupational Fraud and Abuse, 2014, Global Fraud Study.

Ratajczak M., Finansyzacja gospodarki, „Ekonomista” 2012, nr 3.

Rozwój systemu finansowego w Polsce w 2004 r., NBP, Warszawa 2005.

Rozwój systemu finansowego w Polsce w 2005 r., NBP, Warszawa 2006.

Rozwój systemu finansowego w Polsce w 2006 r., NBP, Warszawa 2007.

Rozwój systemu finansowego w Polsce w 2007 r., NBP, Warszawa 2008.

Rozwój systemu finansowego w Polsce w 2008 r., NBP, Warszawa 2009.

Rozwój systemu finansowego w Polsce w 2010 r., NBP, Warszawa 2012. 
Rozwój systemu finansowego w Polsce w 2013 r., NBP, Warszawa 2014.

Rozwój systemu finansowego w Polsce w 2014 r., NBP, Warszawa 2015.

San-Jose L., Retolaza J. L., Urionabarrenetxea S. [et al.], The New Paradigm of Corporate Finance: Ethics in Finance, ICTs, Financial Globalization and Stakeholder Responsibility, „International Research Journal of Finance and Economics” 2013, vol. 103, January.

Schmidt R. H., Tyrell M., What Constitutes a Financial System in General and the German Financial System in Particular, Johann Wolfgang Goethe - Universität Frankfurt am Main Fachbereich Wirtschaftswissenschaften, Working Paper Series: Finance \&Accounting no. 111, 2003, http://hdl.handle.net/10419/76926.

Stownik ekonomii, Wydawnictwo Naukowe PWN, Warszawa 2008.

Słownik finansów i bankowości, Wydawnictwo Naukowe PWN, Warszawa 2008.

Smith A., Theory of Moral Sentiments, Prometheus Books, New York 2000, [w:] H. J. Blommstein, Why is Ethics Not Part of Modern Ecpnomics and Finance? A Historical Perspective, „Finance \& The Common Good/Bien Commun” 2006, no. 24, Spirng/Summer.

Stansbury J., Barry B., Ethics Programs and the Paradox of Control, „Business Ethics Quarterly” 2007, vol. 17, issue 2.

Świecka B., Konsument na rynku finansowych, [w:] G. Rosa (red.), Konsument na rynku ustug, C. H. Beck, Warszawa 2015.

Transparency in Corporate Reporting Assessing the Worlds Largest Companies, http://www.transparency.org/whatwedo/publication/transparency_in_corporate_reporting_assessing_the_worlds_la rgest_companies.

Uchwała Izby Cywilnej SN z 30.04.1999 r., III CZP 61/98. OSNC 1999, nr 12, poz. 201.

Ustawa z 29 sierpnia 1997 r., Prawo bankowe, DzU 1997, poz. 128, ze zm.

Ustawa z 4 września 1997 r., O działach administracji rzadowej, DzU 1999, nr 82, poz. 928, ze zm.

Ustawa z 15 września 2000 r., Kodeks spótek handlowych, DzU 2000, nr 94, poz. 1037, ze zm.

van Hoorn A., The Global Financial Crisis and the Values of Professionals in Finance: An Empirical Analysis, „Journal of Business Ethics” 2015, vol. 130.

Williamson O. E., Masten S., The Economics of Transaction Costs, Edward Elgar Publishing, Northhampton (MA) 1999.

Wypych M., Finanse $i$ instrumenty finansowe, Społeczna Wyższa Szkoła Przedsiębiorczości i Zarządzania, Łódź 2001.

Zadroga A., Świat finansów w perspektywie etycznej, „Rocznik Nauk Społecznych” 2008, nr 3.

Zięba M., OP Wstęp, [w:] J. G. Hulsmann, Etyka produkcji pieniądza, Instytut Ludwiga von Misesa, Warszawa 2014.

77/780/EEC - First Council Directive of 12 December on the Ccoordination of the Laws, Regulations and Administrative Provisions Relating to the Taking up and Pursuit of the Business of Credit Institutions, O. J. nr L322, 17.12.1977.

89/299/EEC - Second Council Directive of 18 December 1989 on the Coordination of the Laws Regulations and Administrative Provisions Relating to the Taking up and Pursuit of the Business of Credit Institutions and Amending Directive 77/780/EEC, O. J. nr L 386, 30.12.1989.

http://www.becker-posner-blog.com/. 


\title{
THE OUTLINE OF THE FINANCE ETHICS
}

\begin{abstract}
The consequences of the crises in the financial markets (as a loss of confidence by customers to the financial system) led to the increased interest in business ethics and especially the ethics of finance. Finance ethics is gradually gaining importance in the scientific discourse. The aim of the paper is to present a conceptual sense and identification catalog of issues related to ethics in finance - a research area of finance ethics and an attempt to assess its multidimensionality. The research question specified in this paper is if the potential hazards occurring in the financial system determine ethical action. The method used to serve the purpose and to find an answer to the research question was a critical analysis of domestic and foreign literature. The analysis showed that there are dilemmas and ethical challenges in operations related to finance, and that should to form in patterns of personal behavior and ethical standards of conduct for employees, managers, institutions and consumers.
\end{abstract}

Keywords: financial system, banking sector, business ethics, finance ethics. 